\title{
Study on the Spatial Distribution of Cities Income and Poverty in Inner Mongolia*
}

\author{
Xiangping Bao \\ College of Political Law and History Culture \\ Jining Normal University \\ Ulanqab, China 012000
}

\begin{abstract}
Poverty has always been an important problem that persecutes sustainable regional development, especially for the less developed areas. Adopting methods of mathematical statistics and ArcGIS spatial analysis, regarding city as research unit, the paper does research on spatial distribution characteristics of income and poverty in Inner Mongolia in 2016. The results show that: (1) The spatial characteristics of per capita disposable income of overall, urban and rural residents in City show that West high East low from east to west, south high north low from south to north and slight drop in the middle. (2) The polarization of per capita disposable income between urban and rural areas is not serious, but poverty areas are more and poverty is more serious on the whole.
\end{abstract}

Keywords-poverty space; income distribution; Inner Mongolia

\section{INTRODUCTION}

In recent years, although Inner Mongolia in recent years has made tremendous achievements in poverty management, due to a number of constraints, accurate poverty alleviation work have a long way to go. The study on poverty spatial distribution made by scholars at home and abroad shows that spatial heterogeneity exists in both large-scale and smallscale, and the geographical types are different [5-6]. Povertycausing factors are diverse, mainly including physical geography factor [7], economic factor [8], population factor [9], and location factor [10]. The study of income and poverty in Inner Mongolia mainly includes spatial heterogeneity of poverty [11-13], characteristics of poverty [14-16], factors causing poverty $[11,12,16]$, and measures to solve difficulties $[11,12,14]$. A few scholars have studied the problem of poverty in minority inhabited areas [17-18]. At present, only a small number of studies made by majority of scholars on poverty in Inner Mongolia make spatial analysis based on poverty data [11-12]. In view of this, this paper takes the leagues and cities of Inner Mongolia as the basic research unit, and carries on the research to the per capita disposable income and the poverty spatial pattern of each league and city in Inner Mongolia based on the per

*Fund projects: Jining Normal University Ph.D. research start-up fund project (jsbsjj1701); Scientific Research Project of Jining Normal University (jsky2018073); Scientific Research Project of Colleges and Universities of Inner Mongolia Autonomous Region (NJZY18233); Project of Philosophy and Social Sciences of Inner Mongolia Autonomous Region (2015 JDB067). capita disposable income data which can reflect the actual income level of the ordinary people more truthfully, in order to provide reference for government departments to effectively promote precision poverty alleviation.

\section{OVERVIEW OF STUDY AREA}

Inner Mongolia is located in the inner Eurasian continent, in the northern frontier of China, adjoining Heilongjiang, Jilin, Liaoning, Hebei, Shanxi, Shaanxi, Ningxia and Gansu provinces (regions) and bordering on Mongolia, and Russia. Inner Mongolia is one of the five minority autonomous regions in China, with a total land area of 1.183 million $\mathrm{km} 2$. The area of Inner Mongolia is vast, and the topography is complicated, showing narrow and long shape. The distance between east and west is $2400 \mathrm{~km}$, and the span between north and south is $1700 \mathrm{~km}$. The climate is dominated by continental monsoon climate in temperate zone, which has the characteristics of less and uneven precipitation, big wind and violent temperature change. There are 9 prefecture-level cities, 3 leagues (12 prefectural-level administrative divisions in total) under the administration of Inner Mongolia. Referring to the relevant literature, Inner Mongolia is divided into the eastern region (including Hulunbeier, Xing'an, Tongliao, Chifeng, and Xilingol) and the western region (including Hohhot, Ulanqab, Baotou, Erdos, Bayannur, Alashan and Wuhai). In 2016, Inner Mongolia Autonomous Region GDP completed 1863.26 billion yuan, and the per capita income GDP reached 74,069 yuan. The per capita disposable income of urban and rural residents was 24,127 yuan, of which 32,975 yuan was per capita disposable income of urban residents and 11,609 yuan was per capita disposable income of rural residents.

\section{DATA SOURCES AND RESEARCH METHODS}

\section{A. Data Sources}

The data used in this paper are mainly from the Inner Mongolia Statistical Yearbook of 2017 and the Inner Mongolia Autonomous Region Statistical Bulletin of National Economic and Social Development of 2016. Some missing data are obtained from the second-hand data of relevant official websites of Inner Mongolia, the statistical data of Inner Mongolia related alliances and articles and reports. 


\section{B. Research Methods}

1) GIS spatial analysis: Using the vector data symbolic method and trend analysis of ArcGIS 9.3 software, this paper analyzes the per capita disposable income and the spatial distribution of poverty in Inner Mongolia and symbolizes it.

2) Median of income: This paper uses the median of per capita disposable income to measure the poverty in Inner Mongolia. Median, also known as the mid-value, represents a value in a sample, population, or probability distribution. It divides the set of values into two equal parts, and often descries the centralized trend of the set of data. Compared to the per capita disposable income, the median of per capita disposable income is closer to the real income level of the general population, since the per capita income may be far greater than the median because of the gap between the rich and the poor, while the median of income may reflect this gap [19].

\section{RESULTS AND ANALYSIS}

\section{A. Spatial Distribution of Income}

1) Classification of urban and rural income: From "Table I", the per capita disposable income of urban and rural residents, urban residents and rural residents in Inner Mongolia in 2016 shows the following characteristics: judging from the per capita disposable income of urban and rural residents, Baotou City ranks first with 35,759 yuan, higher than the other 11 leagues and cities, while Hinggan League is the lowest with 15,468 yuan. According to the per capita disposable income of urban residents, Baotou City is in the first place, with 40,955 yuan, while Hinggan League is the lowest, with only 24,279 yuan. The gap between the two is 16,676 yuan. From the per capita disposable income of rural residents, the gap between urban areas is also relatively large. Alashan League is the highest, with 16,746 yuan, ranking the first, while Xing'an League is the lowest, with 8,533 yuan, and the gap between the two 8,213 yuan.

TABLE I. THE PER CAPITA DisPosABle INCOME OF RESIDENTS IN INNER MONGOLIA IN 2016 (UNIT: YUAN)

\begin{tabular}{llll}
\hline \multicolumn{1}{c}{ Area } & $\begin{array}{c}\text { disposable income of urban } \\
\text { and rural residents }\end{array}$ & $\begin{array}{c}\text { disposable income of urban } \\
\text { residents }\end{array}$ & $\begin{array}{c}\text { disposable income of rural } \\
\text { residents }\end{array}$ \\
\hline Hohhot City & 30527 & 40220 & 14517 \\
Baotou City & 35759 & 40955 & 14692 \\
Hulunbeier City & 24280 & 28885 & 12540 \\
Hinggan League & 15468 & 24279 & 8533 \\
Tongliao City & 18415 & 27444 & 11585 \\
Chifeng City & 17737 & 27336 & 9517 \\
Xilin Gol League & 25554 & 32903 & 138 \\
Ulanqab & 17373 & 26565 & 1585 \\
Erdos City & 32860 & 40221 & 1548 \\
Bayan Nur City & 21010 & 26259 & 1476 \\
Wuhai City & 35566 & 36515 & 15475 \\
Alxa League & 30569 & 34737 & 16746 \\
\hline
\end{tabular}

The vector data symbol method of ArcGIS 9.3 software is used to symbolize the per capita disposable income of urban and rural residents, urban residents and rural residents of Inner Mongolia and it can be divided into four grades according to the natural fracture method in "Fig. 1". On the whole, the spatial characteristic of urban and rural residents, urban residents and rural residents' per capita disposable income is "high in the west, and low in the east". From "Fig. 1 " and "Table I", it can be seen that the spatial characteristic of per capita disposable income of urban and rural residents is "high in the middle and low on both sides". Except for the low per capita disposable income in Bayannur City and
Ulanqab City, that of the other league cities is relatively higher than in the east. From "Fig. 2" and "Table I", it can be seen that the spatial characteristic of per capita disposable income of urban residents is that of the western region is relatively high in the leagues except Bayannur City and Ulanqab City, and in eastern region, that of the other leagues is relatively low except Xilingole League. From "Fig. 3 "and "Table I", it can be seen that the spatial characteristic of per capita disposable income of rural residents is that of the western region is higher than that in the eastern region, except for the lower one in Ulanqab and that of eastern region is generally low. 


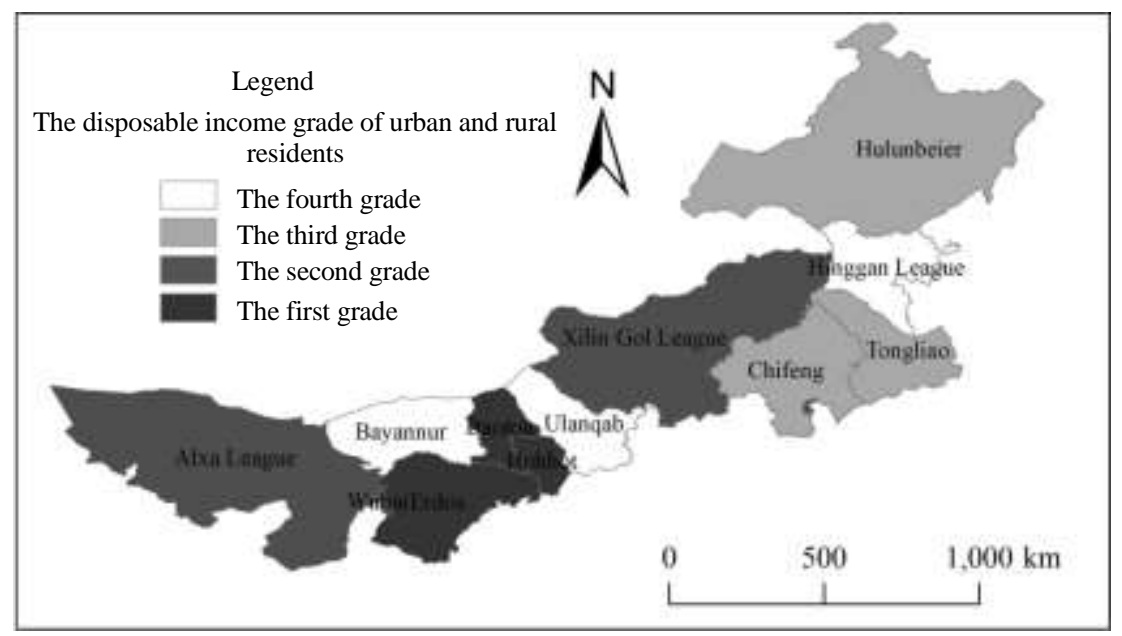

Fig. 1. Spatial distribution class of per capita disposable income grade of urban and rural residents in Inner Mongolia in 2016.

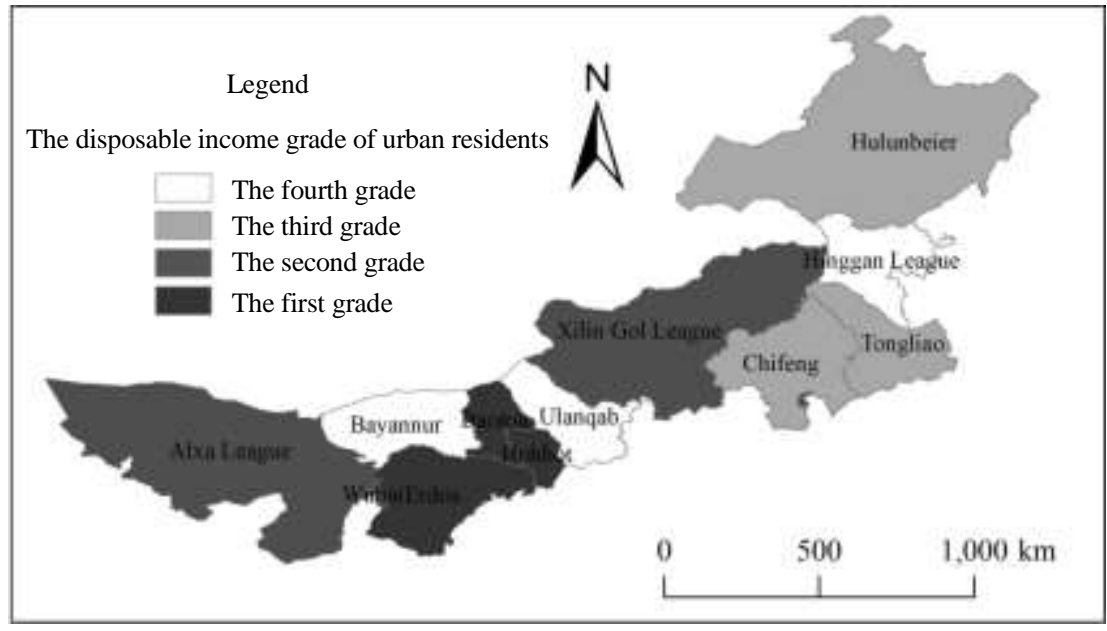

Fig. 2. Spatial distribution class of per capita disposable income grade of urban residents in Inner Mongolia in 2016.

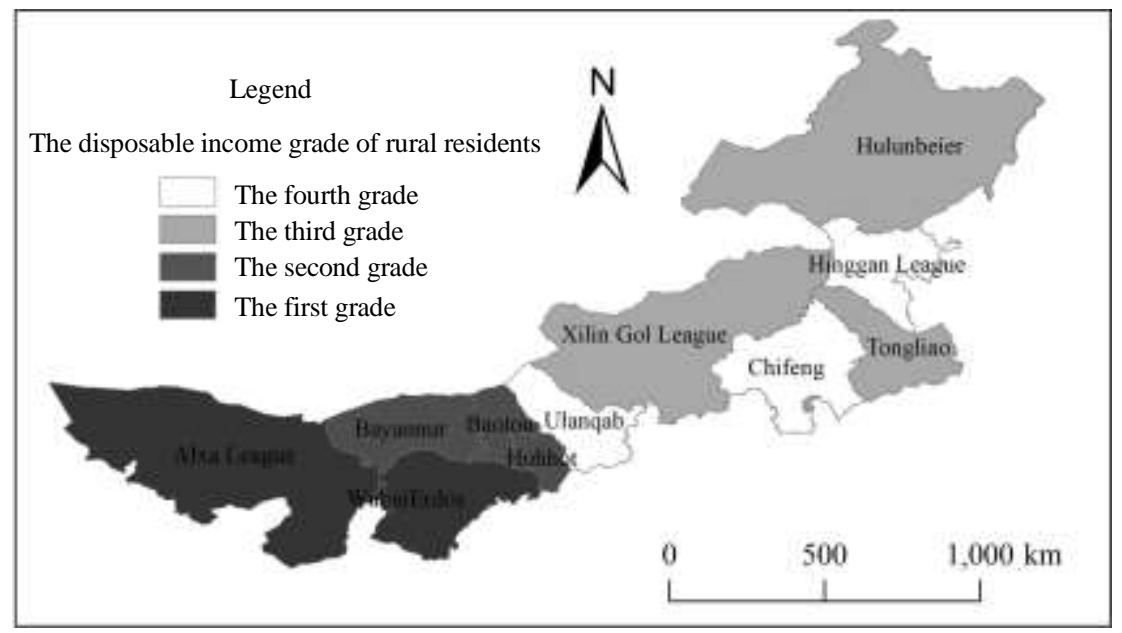

Fig. 3. Spatial distribution class of per capita disposable income grade of rural residents.

2) Spatial difference of urban-rural income: In order to reveal the overall rule of the per capita disposable income space in Inner Mongolia, the trend of per capita disposable income in Inner Mongolia in 2016 is analyzed by ArcGIS 
9.3 software as in "Fig. 4". Each upright bar and sampling point in "Fig. 4" represents the per capita disposable income of urban inhabitants and their spatial location. The per capita disposable income of urban and rural residents, urban residents and rural residents of 12 leagues and cities is projected as scattered point on the $x, z$ plane expressing the east-west direction and the $y, z$ plane expressing the south-north direction. All projection points in the $x, Z$ direction and $y, z$ direction form an optimal trend simulation curve. From "Fig. 4", "Fig. 5" and "Fig. 6", it can be known that the spatial distribution of per capita disposable income of urban and rural residents, urban residents and rural residents of Inner Mongolia in 2016 shows a trend of high in the west and low in the east, low in the north and high in the south, with a slightly decreasing trend in the middle, basically showing an inverted "U" distribution. Therefore, the spatial heterogeneity of per capita disposable income in urban and rural areas of Inner Mongolia in 2016 is obvious.

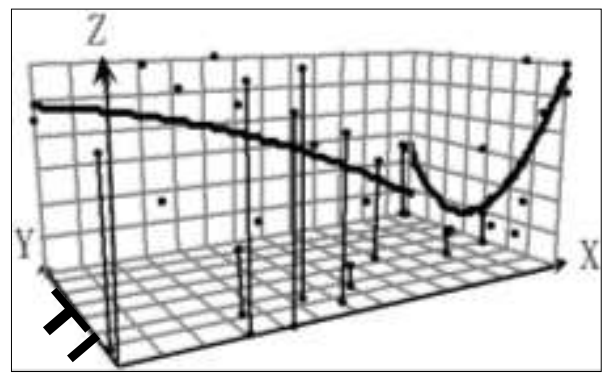

Fig. 4. Spatial distribution tendency of per capita disposable income of urban and rural residents in Inner Mongolia in 2016.

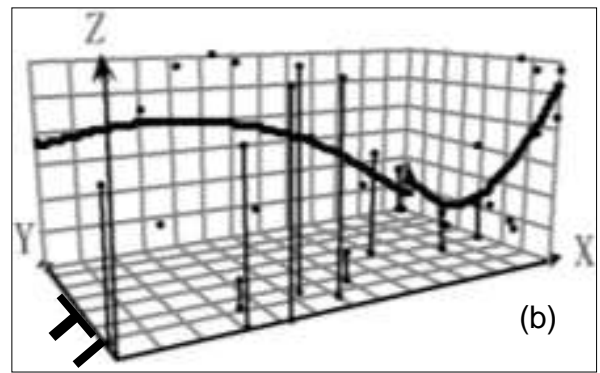

Fig. 5. Spatial distribution tendency of per capita disposable income of urban residents in Inner Mongolia in 2016.

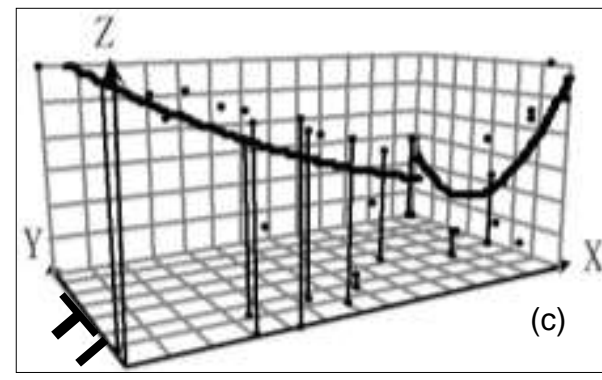

Fig. 6. Spatial distribution tendency of per capita disposable income of rural residents in Inner Mongolia in 2016.

\section{B. Poverty Spatial Distribution}

In order to further clarify the research objectives, this paper chooses the central per capita disposable income as an important index in the process of poverty measurement to study [20]. Therefore, this paper chooses the per captia disposable income of urban residents in Inner Mongolia in 2016 to analyze.

1) Descriptive statistics of urban and rural income: Because the living cost in cities and towns is higher than that in rural areas, the income of basic living will is higher than that in rural areas. However, according to the distribution of per capita disposable income in Inner Mongolia, the polarization of per capita disposable income in urban and rural areas, rural areas and urban areas is not serious. Based on the data in "Table I", this paper uses SPSS 19.0 software for statistical analysis, and the results are as follows in "Table II".

TABLE II. StatisticAl DESCRIPTION OF PER CAPITA DisPosable INCOME OF ReSidents IN INNER MONGOLIA IN 2016

\begin{tabular}{llll}
\hline \multicolumn{1}{c}{ statistical magnitude } & $\begin{array}{c}\text { disposable income of urban and } \\
\text { rural residents (yuan) }\end{array}$ & $\begin{array}{c}\text { Per capita disposable income of } \\
\text { urban residents (yuan) }\end{array}$ & $\begin{array}{c}\text { Per capita disposable income of } \\
\text { rural residents (yuan) }\end{array}$ \\
\hline $\mathbf{N} \quad$ valid & 12 & 12 & 12 \\
mean value & 0 & 0 & 0 \\
median & 25426.5000 & 32193.2500 & 12986.1667 \\
mode & 24917.0000 & 30894.0000 & 13832.0000 \\
standard deviation & $15468.00 \mathrm{a}$ & $24279.00 \mathrm{a}$ & $8533.00 \mathrm{a}$ \\
skewness & 7449.4885 & 6163.7822 & 2752.0364 \\
kurtosis & 0.113 & 0.309 & -0.504 \\
Minimum value & -1.642 & -1.638 & -1.096 \\
maximal value & 15468.00 & 24279.00 & 8533.00 \\
\hline
\end{tabular}


"Table II" shows that the average per capita disposable income of urban and rural residents are 32193 yuan and 12986 yuan respectively, and the per capita disposable income of urban residents is about 2.5 times that of rural residents. From the point of view of per capita disposable income standard deviation, the standard deviation of per capita disposable income of urban and rural residents is larger, indicating that the income data is relatively scattered, and the income gap is relatively large. From the skewness of per capita disposable income in urban and rural areas, rural areas and urban areas, it can be seen that the three types of per capita disposable income have a skewed distribution. Since the kurtosis values are less than 0 , the three types of per capita disposable income show a flat peak distribution, indicating that the representativeness of median and mode is better than that of mean value.

2) Identification criteria for poverty within city: Since the urban and rural residents per capita disposable income data shows a right-biased distribution, and per capita disposable income of rural residents shows a left-biased distribution, the representation of median is good. Therefore, this paper takes the median as the bound to divide the data of per capita disposable income of urban and rural residents and that of urban residents into two parts. However, because the data on the left side is more concentrated than that on the right side, it is not reasonable to take the unified standard deviation as the group distance. We should calculate the left standard deviation $S_{1}$ and the right standard deviation $S_{2}$ of median $M$ respectively. Based on $M-2 S_{1}, M-S_{1}, M+S_{2}$ and $M+2 S_{2}$, the per capita disposable income of urban and rural residents and urban residents is divided into five regions [21]. The per capita disposable income of rural residents is divided into two parts. However, because the data on the right side is more concentrated compared to that on the left, it is not reasonable to use the unified standard deviation as the group distance. We should separately calculate the left standard deviation $S_{1}$ and right standard deviation $S_{2}$ of the median $M$. In this paper, the per capita disposable income of rural residents is divided into five regions based on $M-2 S_{2}$, $M-S_{2}, M+S_{1}$ and $M+2 S_{1}$, as shown in "Table III".

TABLE III. CRITERION OF IDENTIFICATION OF CITY POVERTY

\begin{tabular}{lll}
\hline \multicolumn{1}{c}{$\begin{array}{c}\text { Identification Criteria for Urban and Rural } \\
\text { Poverty }\end{array}$} & \multicolumn{1}{c}{$\begin{array}{c}\text { identification standard of rural } \\
\text { poverty }\end{array}$} & type of region \\
\hline$\left[\min (\right.$ income $\left.), M-2 S_{1}\right]$ & {$\left[\min (\right.$ income $\left.) M-2 S_{2}\right]$} & poor regions \\
{$\left[M-2 S_{1}, M-S_{1}\right]$} & {$\left[M-2 S_{2}, M-S_{2}\right]$} & relatively poor regions \\
{$\left[M-S_{1}, M+S_{2}\right]$} & {$\left[M-S_{2}, M+S_{1}\right]$} & general regions \\
{$\left[M+S_{2}, M+2 S_{2}\right]$} & {$\left[M+S_{1}, M+2 S_{1}\right]$} & relatively rich regions \\
{$\left[M+2 S_{2}, \max (\right.$ income $)$} & {$\left[M+2 S_{1}, \max (\right.$ income $)$} & rich region \\
\hline
\end{tabular}

According to the identification standard of poverty and 2016 is obtained by calculation of SPSS 19.0. The results are the method of classification of regional types in "Table III", the identification standard of poverty in Inner Mongolia in as in "Table IV".

TABLE IV. CRITERION OF IDENTIFICATION OF COUNTY POVERTY IN INNER MONGOLIA IN 2016

\begin{tabular}{llll}
\hline $\begin{array}{c}\text { identification standard of urban } \\
\text { and rural poverty }\end{array}$ & $\begin{array}{c}\text { identification standard of } \\
\text { urban poverty }\end{array}$ & $\begin{array}{c}\text { identification standard of } \\
\text { rural poverty }\end{array}$ & type of region \\
\hline$[15468,17578]$ & {$[24279,27828]$} & {$[8533,9928]$} & poor regions \\
& {$[27828,29361]$} & {$[9928,11880]$} & relatively poor regions \\
{$[17758,21888]$} & {$[29361,34253]$} & {$[11880,14702]$} & general regions \\
{$[21888,28739]$} & {$[34253,37612]$} & {$[14702,15572]$} & relatively rich regions \\
{$[28739,32563]$} & {$[37612,40955]$} & {$[15572,16746]$} & rich region \\
{$[32563,35759]$} & & & \\
\hline
\end{tabular}

3) Spatial pattern of poverty within city: Twelve leagues of Inner Mongolia are classified and symbolized according to the identification criteria in "Fig. 7". From the perspective of urban and rural areas, as shown in "Fig. 7", there are 2 poor regions, 3 relative poor regions and 2 general regions.
From the perspective of urban area as shown in "Fig. 8", there are five poor regions, one relative poor region and one general region. From the perspective of rural area as shown in "Fig. 9", there are three poor regions, one relative poor region and four general regions. 


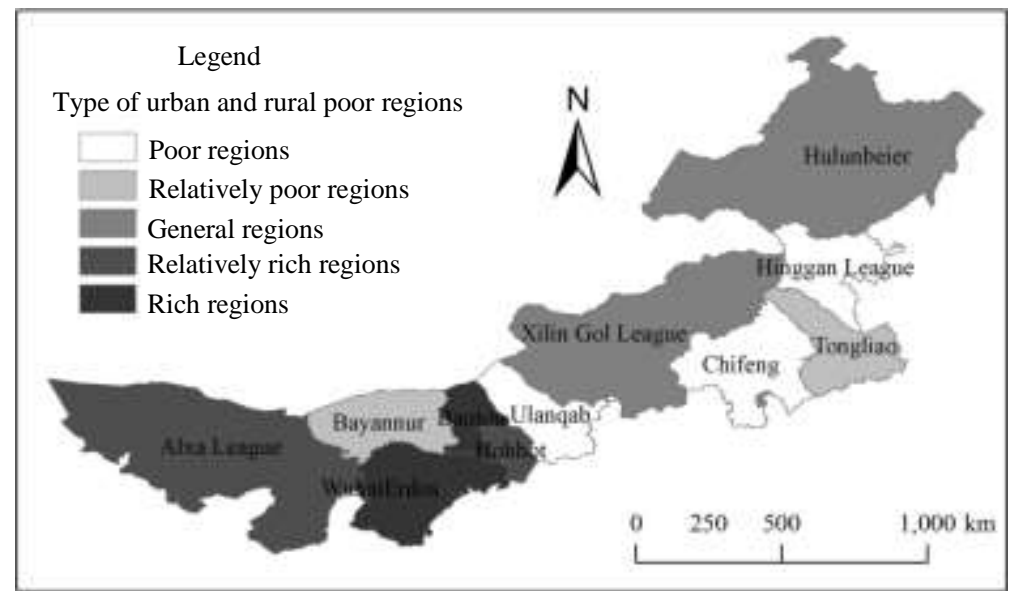

Fig. 7. Spatial distribution of poverty regions of urban and rural areas in Inner Mongolia in 2016.

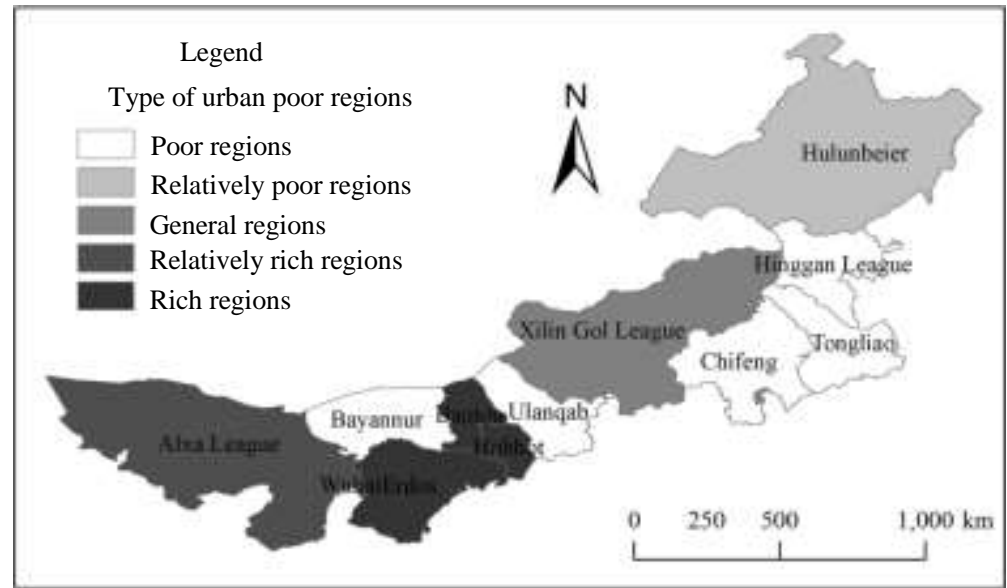

Fig. 8. Spatial distribution of poverty regions of urban areas in Inner Mongolia in 2016.

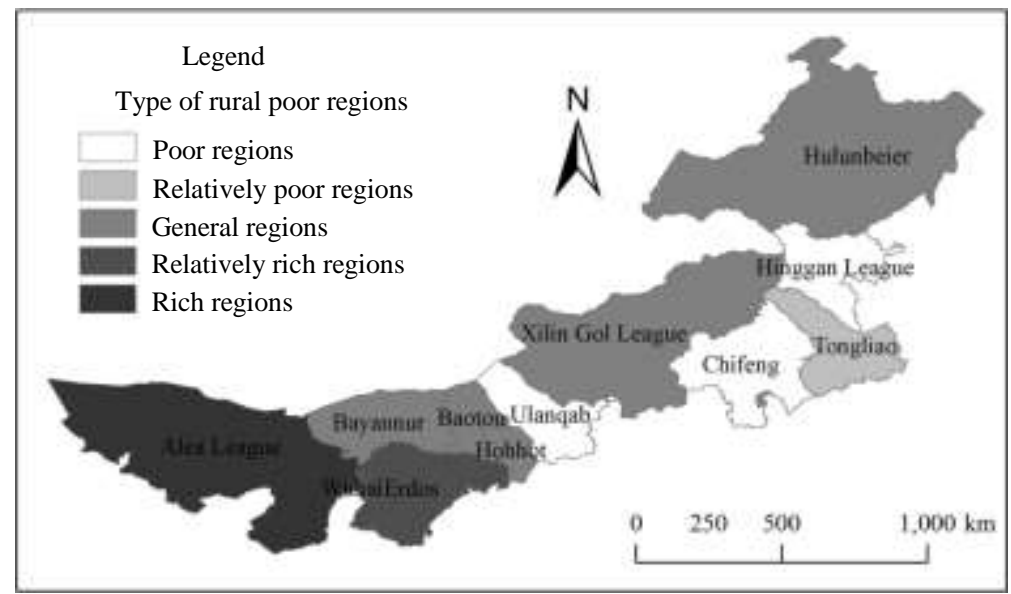

Fig. 9. Spatial distribution of poverty regions of rural areas in Inner Mongolia in 2016.

\section{CONCLUSION}

\section{A. Conclusion}

Taking Inner Mongolia leagues as the basic research unit, this paper analyzes the per capita disposable income and poverty spatial characteristics of urban residents in Inner Mongolia in 2016 by using the methods of mathematical statistics and ArcGIS spatial analysis method. The main conclusions are as follows:

- From the perspective of income grades, the spatial characteristic of per capita disposable income in urban and rural areas, urban areas and rural areas of Inner Mongolia in 2016 is "high in the west and low in the east". As for the per capita disposable income 
of urban and rural residents, except Bayannur City and Ulanqab City, the other leagues and cities in eastern region are relatively higher than the eastern region. Judging from the per capita disposable income of urban residents, the western regions except Bayannur City and Ulanqab City are on the low side, the other league cities are relatively high, the eastern regions except Xilingole League are relatively high, and the other league cities are relatively low. As for the per capita disposable income of rural residents, the western region except the city of Ulanqab is significantly higher than the eastern region.

- Judging from the difference of income, in 2016, the spatial distribution of per capita disposable income in urban and rural areas, urban areas and rural areas of Inner Mongolia shows the trend of low in east and high in west from south to north, low in north and low in middle, showing the distribution of inverted "U" type basically.

- From the perspective of poverty level, the polarization of disposable income per capita among urban and rural residents is not serious, but there are more poor regions and the whole is not rich enough. Therefore, the task of poverty alleviation has a long way to go.

\section{B. Discussion}

- In recent years, scholars at home and abroad use different methods and indicators to measure poverty, and they are more inclined to use multi-dimensional index comprehensive measures. In this paper, the per capita disposable income index is used to measure the urban poverty. To some extent, the calculated results can reflect the real situation of the urban poverty in Inner Mongolia.

- The formation of poverty is a long-term process. If we want to approach its essence, a long-term and indepth anatomical analysis should be made. In this paper, only the poverty status of Inner Mongolia in 2016 is analyzed, and the long-term series of research hasn't been made, so further in-depth study need to be made by collecting data.

- Because of the limitation of space, this paper does not discuss the formation mechanism of poverty in Inner Mongolia, so the author should make more efforts in these aspects in the future.

\section{REFERENCES}

[1] Green A E.The geography of poverty and wealth[M].Warwick UK:The Institute for Employment Research, University of Warwick, 1994.

[2] Katherine J Curtis, Paul R Voss, David D. Long.Spatial variation in poverty-generating processes:Child poverty in the United States[J]. Social Science Research, 2012, (41): 14-59.

[3] Ding Jianjun. A Comparative Study of Poverty in 11 Particularly Distressed Areas in China - based on the perspective of calculation of comprehensive development index [J]. Geography, 2014, 34 (12),
1418-1427. 丁建军.中国 11 个集中连片特困区贫困程度比较研究 基于综合发展指数计算的视角 [J]. 地理科学, 2014 34(12),1418-1427.

[4] Epprecht M, Müller D, Minot N. How remote are Vietnam's ethnic minorities? An analysis of spatial patterns of poverty and inequality[J].The Annals of Regional Science, 2011, 46(2):349-368.

[5] Guo Laixi, Jiang Dehua. Study on environmental types of poor areas in China [J]. Geographical Research, 1995, 24 (2): 1-7. 郭来喜,姜德 华.中国贫困地区环境类型研究[J].地理研究,1995,24(2): 1-7.

[6] Wang Yongming, Wang Meixia, Wu Dianting, et al. Analysis of Spatial Pattern and Formation Mechanism of Rural Poverty in Guizhou Province [J]. Scientia Geographica Sinica, 2017, 37 (2): 217-227. 王永明,王美霞,吴殿廷,等.贵州省乡村贫困空间格局与形 成机制分析[J].地理科学,2017,37(2):217-227.

[7] Okwi P O, Ndeng'e G, Kristjanson P et al.Spatial determinants of poverty in rural Kenya[J].Proceedings of the National Academy of Sciences of the United States of America, 2007, 104(43):1676916774.

[8] Ding Jianjun. Evolvement of Poor Economic Growth and Spatia Differences in Wuling Mountain Region Based on Empirical Analysis of Urban Data from 2000 to 2011 [J]. Geographical Research, 2014 33 (5): 948-960. 丁建军.武陵山片区经济增长益贫性与空间差异演 变——基于 2000 2011 年市域数据的实证分析[J].地理研究, 2014 33(5): 948-960.

[9] Gustafsson B, Li S. The ethnic minority-majority income gap inrural China during transition[J].Economic Development and Cultural Change, 2003, 51(4): 805-822.

[10] Partridge M, Rickman D. Distance from urban agglomeration economics and rural poverty[J].Journal of Regional Science, 2008, 48(2):285-310

[11] Jin Zhaoxin. Study on the Spatial Differentiation of Poverty in Inner Mongolia and the Factors Causing Poverty and Eliminating Poverty [D]. Hohhot: Inner Mongolia University, 2017. 金肇馨.内蒙古贫困 空间分异及致贫消贫因素研究[D].呼和浩特:内蒙古大学硕士学位 论文, 2017.

[12] Pan Bin, Zhong Min, Wang Zhijuan. Distribution and cause of poverty population in Inner Mongolia and typical cases of withdrawal from poor counties [J]. Jiangsu Agricultural Sciences, 2017, 45 (8): 333-337. 潘斌,钟敏,王志娟.内蒙古贫困人口的分布、成因及其贫 困县退出典型案例分[J].江苏农业科学,2017,45(8):333-337.

[13] Chen Zuhai, Xie Hao. Analysis of Poverty Heterogeneity in Arid Pastoral Areas Based on Investigation of Siziwang Banner, Inner Mongolia Autonomous Region [J]. Journal of South-Central University for Nationalities:Humanities and Social Science, 2015, 35 (1): 108-113. 陈祖海,谢浩.干旱牧区贫困异质性分析一一基于内蒙 古自治区四子王旗的调查 $[\mathrm{J}]$. 中南民族大学学报(人文社会科学 版),2015,35(1):108-113.

[14] Zhang Lijun, Yang Xiuming, Yu Qian. Comparative Analysis and countermeasure study of Poverty Characteristics in Inner Mongolia under the Background of Accurate Poverty Alleviation [J]. Inner Mongolia Social Sciences (Chinese Version), 2017, 38 (4): 199-204. 张丽君,杨秀明,于倩.精准扶贫背景下内蒙古贫困特征比较分析及 对策研究[J].内蒙古社会科学(汉文版),2017,38(4):199-204.

[15] Sun Lin, Wang Yanhui, Ke Wenjun, et al. Calculation and Analysis of Multidimensional Poverty Characteristics of Rural Population in Inner Mongolia Autonomous Region [J]. Cultural Geography, 2016 , 31 (1): 108-115. 孙林,王艳慧,柯文俊,等.内蒙古自治区农村人口多 维贫困特征测算与分析[J].人文地理,2016,31(1):108-115.

[16] Hai Shan. Study on Poverty Problems and Countermeasures for Poverty Alleviation and Development in Pastoral Areas of Inner Mongolia [J]. Chinese Journal of Animal Science, 2007, 43 (10): 4550. 海山.内蒙古牧区贫困化问题及扶贫开发对策研究 [J].中国畜牧 杂志, 2007,43(10):45-50

[17] Zhang Aili. An Analysis of Poverty in Mongolian Inhabited Areas from the Perspective of Multidimensional Culture: A Case Study of Tongliao City, Inner Mongolia Autonomous Region [J]. Inner Mongolia Social Sciences (Chinese Version), 2012, 33 (1): 80-84 张 艾力.多维文化视角下蒙古族聚居区贫困问题探析- - 以内蒙古 自治区通辽市为例 [J].内蒙古社会科学(汉文版), 2012,33(1):80-84. 
[18] Wang Sumin. The Source of Mongolian Village Poverty Problem and Poverty Relief Pattern from the Perspective of Accurate Poverty Alleviation: A Case Study of Mongolian Village in Tongliao City, Inner Mongolia [J]. Heilongjiang National Series, 2016 (5): 64-68. 王 苏敏.精准扶贫视域下蒙古族村落贫困问题与脱贫模式探源一 以内蒙古通辽市蒙古族村落为例 [J]. 黑龙江民族丛刊,2016(5):6468.

[19] Shen Yong. Median of disposable income per capita is favorable to reflect the gap between rich and poor [N]. Shenzhen Special Zone Daily, 2012-9-21 (A19). 沈勇. 人均可支配收入中位数有利反映贫 富差距[N].深圳特区报, 2012-9-21( A19).

[20] Li Jingyi, Wang Yanhui. Spatial Coupling Characteristics of Ecological Environment Quality and Economic Poverty in Luliang Area [J]. Chinese Journal of Applied Ecology, 2015,25(6): 1715-1724. 李静怡,王艳慧.吕梁地区生态环境质量与经济贫困的空间耦合特 征[J].应用生态学报,2015,25(6): 1715-1724.

[21] Feng Yan. Research on Regional Poverty Measurement, Identification and Anti-Poverty Path Selection [D]. Shenyang: Liaoning University, 2015. 冯艳. 区域贫困测度、识别与反贫困路 径选择研究[D].沈阳:辽宁大学博士学位论文,2015. 